\title{
Shiva Kaivanpanah
}

University of Tehran, Tehran, Iran

shkaivan@ut.ac.ir

\section{Sayyed Mohammad Alavi \\ University of Tehran, Tehran, Iran \\ smalavi@ut.ac.ir}

\section{Ian Bruce}

University of Waikato, Hamilton, New Zealand

ibruce@waikato.ac.nz

\section{S. Yahya Hejazi*}

University of Tehran, Tehran, Iran

s.yahya.hejazi@ut.ac.ir

\section{IRANIAN EAP PRACTITIONERS' COMPETENCES, PRACTICES, AND PROFESSIONAL DEVELOPMENT}

\section{Abstract}

Given the importance of teaching methodology in English for Academic Purposes (EAP) and professional development (PD) for EAP teachers, this survey examined and explored the differences of the self-adjudged perceptions of EAP practice competences and PD activities of two main groups of Iranian teachers: those with an English language teaching (ELT) background and subject content teachers who teach EAP. A sample of 105 EAP teachers (53 English language teachers and 52 content teachers) responded to two questionnaires: a granulated, 72-item questionnaire exploring competences in a wide variety of aspects of EAP practice and a smaller 19-item questionnaire relating to frequency of participation in PD activities. Additionally, the teacher data sets were triangulated by the use of a 58 -item questionnaire completed by 502 Iranian undergraduate students taking EAP courses. The teacher questionnaire findings indicated higher self-adjudged competences by the ELTbackground teachers in the areas of receptive and productive skills, grammar and vocabulary, feedback and error correction, and assessment and evaluation. Similarly, the student questionnaires rated those teachers with an ELT background more highly in the same five areas. The implications of the findings for the future development of EAP in Iran in terms of teacher development and further research are then discussed.

\section{Key words}

English for academic purposes (EAP), teachers, teaching competence, professional development, classroom practices, Iran.

\footnotetext{
* Corresponding address: S. Yahya Hejazi, English Department, Faculty of Foreign Languages and Literature, University of Tehran, Tehran, Iran. (Post Code: 1439813164)
} 


\section{INTRODUCTION}

English for Academic Purposes (EAP), as an important branch of English for Specific Purposes (ESP), has traditionally been responsible for teaching "specialized linguistic knowledge and literacy skills" (Pérez-Llantada \& Swales, 2017: 42) to prepare tertiary students and researchers for successful communication in academic and research settings. EAP courses subdivide into general EAP courses (EGAP) for students preparing to study in a range of disciplines and specific EAP courses (ESAP) for students preparing to study in a specific discipline. The focus of the research reported here relates to teachers of ESAP courses, who are involved in the preparation of students for discipline-specific academic study (rather than professional practice), but for whom the insights of much of the ESP literature is considered relevant and drawn upon extensively here.

To inform the activities of ESP (and EAP), research to date has addressed a range of areas such as student needs analysis, materials development and evaluation, and discourse analysis (Hyland, 2019). In considering the range of research activities of the allied fields of ESP and EAP, a number of writers note that the focus has been mainly on the two areas of students and materials/textbooks, which are regarded as the essential elements of any language teaching and learning program (Hutchinson \& Waters, 1987; Richards, 1998). Exemplifying this view, a considerable body of ESP research has addressed students and their needs (Bocanegra-Valle, 2016; Hyland, 2019) as well as materials/textbooks (Basturkmen \& Bocanegra-Valle, 2018; Stoller, 2016). Similarly, when considering the larger body of EAP research, the literature on EAP teachers (vis-à-vis other areas of EAP) is relatively limited (Ding, 2019; Ding \& Bruce, 2017; Ding \& Campion, 2016). The situation seems to be that issues relating to teachers' practices, professional development, and needs have been eclipsed by the large body of research on materials and students' needs (Basturkmen, 2014, 2019). Belcher (2013: 544) even suggests that "the community that ESP [and EAP] professionals know the least about is their own".

A decade ago, Hamp-Lyons (2011: 100) also decried this lack of focus on the EAP practitioner, asserting that "progress in materials development has not been matched by progress in developing and delivering professional training courses for future teachers of EAP, and a great need still remains in this area". A recent review article by Nazari (2020) and studies of the bibliometrics of journals in the EAP and ESP fields (Hyland \& Jiang, 2021; Liu \& Hu, 2021; Riazi, Ghanbar, \& Fazel, 2020) also highlighted the limited range of research on EAP teachers. Thus, although such programs are becoming increasingly widespread around the world, it seems that only marginal research attention has been paid to the training, development, and practices of teachers (Basturkmen, 2014, 2019; Belcher, 2013).

Because of the demanding nature of their profession, EAP and ESP teachers play multiple roles beyond classroom teaching (Charles \& Pecorari, 2016; DudleyEvans \& St. John, 1998). According to Woodrow (2018), their roles and 
responsibilities include needs analysis, course design, materials development, collaboration with subject-matter teachers, analysis of discipline-specific discourse, and course/program evaluation. Similarly, Brown (2016) states that ESP teachers play a central role in developing their field, the four main pillars of which are identified by Anthony (2018) as materials and methods, needs analysis, learning objectives, and evaluation. Yet, despite this "plurality of identities, roles, contexts, and praxis" (Ding \& Campion, 2016: 548), to date only a small body of research on teachers has been carried out in a few countries (e.g. Bocanegra-Valle \& Basturkmen, 2019; Campion, 2016; Chang, 2017; Li \& Ma, 2020; Li \& Wang, 2018; Nguyen, Haworth, \& Hansen, 2019). Considering the diversity of EAP contexts in inner circle, outer circle, and particularly in expanding circle countries (Ding \& Bruce, 2017), further research is required to shed light on, among other things, EAP teachers' practices, teaching competences, and professional development (PD) activities.

This wider situation of a dearth of EAP (and ESP) practitioner-related research is also reflected in the expanding-circle country context of Iran (Kaivanpanah et al., 2021). Similar to other contexts, an increasing body of research has focused on learner needs as well as on EAP textbooks in several university majors (e.g. Atai \& Hejazi, 2019; Atai \& Nazari, 2011; Atai \& Shoja, 2011; Mazdayasna \& Tahririan, 2008; Soodmand Afshar \& Movassagh, 2016). However, only a limited number of studies (e.g. Atai \& Fatahi-Majd, 2014; Atai \& Nejadghanbar, 2017; Atai \& Taherkhani, 2018; Iranmehr, Atai, \& Babaii, 2018) have exclusively addressed issues relating to EAP teachers. Therefore, given the situation that EAP and ESP research has remained highly focused on teaching (Anthony, 2018; Hyland \& Wong, 2019), the importance of teaching methodology (Hafner \& Miller, 2019; Hyland, 2006; Northcott, 2013), and that there is still a paucity of research on EAP teachers' PD generally (Ding \& Bruce, 2017), it is argued here that there is a pressing need in the Iranian context (as elsewhere) to undertake further systematic studies to fill the research gap relating to EAP teachers' classroom practices, teaching competence, and PD activities.

\section{THE STUDY CONTEXT}

As Dudley-Evans and St. John (1998) maintain, contextual differences determine learners' needs and the appropriate levels of specificity in ESP and EAP programs. In Iran, as an expanding-circle country in the Middle East, mainstream education at tertiary level is delivered in Persian, the country's official language. Undergraduate students are required to take one general English course, known as English for General Academic Purposes (EGAP), as well as a few discipline-based EAP courses, characterized as English for Specific Academic Purposes (ESAP) to become prepared to access textbooks and publications in English during their undergraduate and graduate studies (Tavakoli \& Tavakol, 2018). While all EGAP courses are implemented and administered by ELT departments and taught by 
English language (EL) teachers, ESAP courses are mostly taught by content teachers and a limited number of content-informed EL teachers (Atai \& FatahiMajd, 2014). The focus of the present study is on ESAP teachers. It should be noted that although ESAP courses are included in subject-matter curricula (e.g. chemical engineering, psychology, physical education), the national curriculum does not explicitly state who should teach them (Taherkhani, 2019). Additionally, while EL teachers can benefit from a wide range of PD opportunities and activities, there are unfortunately no well-established teacher training/education programs and PD opportunities for ESAP teachers.

Substantial criticism of the current Iranian EAP system at tertiary level has been expressed concerning, inter alia, issues directly related to ESAP teachers and their education/training (Iranmehr et al., 2018). The background to this critique is that there are no formal, established ESAP teacher training programs in Iran. ESAP courses are taught by either content teachers who possess a level of English proficiency or content-informed EL teachers, and there is little or no collaboration or cooperation between the two groups. While this situation is generally wellknown, the present study sought to examine more closely the knowledge and practice competences as well as the professional development of these two teacher groups. (RQs):

Therefore, the study was motivated by the following research questions

RQ1: Is there any statistically significant difference between ESAP teachers (content \& EL) regarding their beliefs about their ESAP teaching competence?

RQ2: Is there any statistically significant difference between ESAP teachers (content \& EL) in terms of their PD activities?

RQ3: Is there any statistically significant difference between ESAP teachers' (content \& EL) classroom practices as reported by their students?

\section{METHOD}

The study is a response to Basturkmen's $(2014,2019)$ call for more in-depth, empirical research on teachers in a wide variety of contexts, in this case the Iranian context, and specifically the previously highlighted issue of ESAP practitioners. The overall design framework of the study is interpretive, the research style (Cohen, Manion, \& Morrison, 2011) is survey, and the data collection instruments used are fixed-response item questionnaires. The purpose of this survey research was to provide a panoramic overview of the main trends and tendencies in current Iranian ESAP practice by the two main teacher groups. The 'panoramic overview' approach was taken to provide empirical evidence for a structural situation in the wider context of ESAP teaching in Iran. It was considered that, given the nature of the issue under investigation, the research questions asked, and the ethical issues 
involved, this 'big picture' approach was more appropriate than more granulated research styles such as ethnography or case study.

\subsection{Participants}

There were two main groups of participants in this study: ESAP teachers and undergraduate students. Specifically, 105 ESAP teachers (53 EL teachers and 52 content teachers) were surveyed for the purposes of the study. The ESAP teacher group included several teachers who taught the students in this study and other teachers chosen via convenience and snowball sampling. The teachers were from several academic majors $(\mathrm{N}=16)$ and leading state universities $(\mathrm{N}=15)$. Two groups of teachers were identified through the questionnaires for comparative purposes in the analysis - those with an English language teaching background (EL teachers) and subject content teachers who also taught ESAP (content teachers). In addition, a total of 502 undergraduate students taking ESAP courses were chosen through random cluster sampling in the 2018-2019 academic year. To ensure sample representativeness, they were selected from a wide range of majors $(\mathrm{N}=21)$ and a large number of leading state universities $(\mathrm{N}=15)$. The students were taught by either EL teachers (52.6\%, N=264) or content teachers $(47.4 \%, \mathrm{~N}=238)$. Table 1 provides a detailed profile of the participants' demographic information.

\begin{tabular}{|c|c|}
\hline ESAP TEACHERS & UNDERGRADUATE STUDENTS \\
\hline $\mathbf{N}=105$ & $\mathbf{N}=502$ \\
\hline Gender: $38.1 \%$ female, $61.9 \%$ male & Gender: $58 \%$ female, $42 \%$ male \\
\hline $\begin{array}{l}16 \text { majors: TEFL, Business Administration, Chemical } \\
\text { Engineering, Computer Engineering, Educational Psychology, } \\
\text { Electrical Engineering, History, Mechanical Engineering, } \\
\text { Metallurgy Engineering, Mining Engineering, Petroleum } \\
\text { Engineering, Philosophy, Physical Education, Physics, } \\
\text { Sociology, Textile Engineering }\end{array}$ & $\begin{array}{l}21 \text { Majors: Business Administration, Chemical Engineering, } \\
\text { Computer Engineering, Dentistry, Educational Psychology, } \\
\text { Electrical Engineering, History, Industrial Engineering, } \\
\text { Mechanical Engineering, Medicine, Metallurgy Engineering, } \\
\text { Midwifery, Mining Engineering, Nursing, Petroleum } \\
\text { Engineering, Pharmacy, Philosophy, Physical Education, } \\
\text { Physics, Sociology, Textile Engineering }\end{array}$ \\
\hline 15 universities & 15 universities \\
\hline $\begin{array}{l}\text { Age range: Below } 30(4.8 \%), 30-35(33.3 \%), 35-40 \\
(31.4 \%) \text {, over } 40(30.5 \%)\end{array}$ & \multirow[t]{2}{*}{ Age range: $18-22$ (84.9\%), 22-26 (14.1\%), 26-30 (1\%) } \\
\hline Degree: Masters (42.9\%), PhD (57.1\%) & \\
\hline $\begin{array}{l}\text { Teaching experience: below } 5 \text { years }(45.7 \%), 5-10 \text { years } \\
(36.2 \%), 10-15 \text { years }(10.5 \%), 15-20 \text { years }(3.8 \%) \text {, over } 20 \\
\text { years }(3.8 \%)\end{array}$ & \multirow[t]{2}{*}{ Taught by EL teachers $(N=264)$ \& content teachers $(N=238)$} \\
\hline EL teachers $(N=53) \&$ content teachers $(N=52)$ & \\
\hline
\end{tabular}

Table 1. Participants' demographic information 


\subsection{Instruments}

Based on Dörnyei's (2010) steps for questionnaire development, three Likert-scale questionnaires were designed to explore ESAP teachers' teaching competence, PD activities, and classroom practices. The statements in questionnaires were developed based on BALEAP's Competency Framework for Teachers of English for Academic Purposes (CFTEAP) and Teachers of English for Academic Purposes (TEAP) documents (BALEAP, 2008, 2014) as well as the results of preparatory unstructured interviews with EAP and content teachers who participated in a related project (Hejazi, 2021). The questionnaires relating to teaching competences and classroom practices drew on Alexander (2012), Atai and Fatahi-Majd (2014), Atai and Hejazi (2019), Chostelidou, Griva, and Tsakiridou (2009), and Rajabi, Kiany, and Maftoon (2012). In addition, the professional development questionnaire was designed based on previous questionnaires by Jing (2010) and Wichadee (2012). Then, the questionnaires were examined and revised to enhance their clarity, content-relatedness, and format by a reference panel of applied linguistics professors, EAP teachers, and psychometricians $(\mathrm{N}=8)$. The questionnaires were originally designed in English, but translated into Persian and back-translated to English with the help of some EAP teachers and translation experts in order to make sure about the quality of the translation. Finally, some additional modifications were undertaken to improve the questionnaires based on a pilot study with representative samples of ESAP teachers and undergraduate students.

Following the common practice for scale development and validation (Hair et al., 2010; Worthington \& Whittaker, 2006), Confirmatory Factor Analysis (CFA) was run in Amos (Version 23) to verify the factor structure of the questionnaires, that is to ensure that the questions were actually measuring the construct that the researchers intended to measure. Higher factor loadings for items indicate that they are suitable to measure the intended construct.

\begin{tabular}{|c|l|c|c|c|c|c|c|c|c|}
\hline No. & \multicolumn{1}{|c|}{ Factor } & Item numbers & Alpha & CMIN & DF & CMIN/DF & GFI & AGFI & RMSEA \\
\hline 1 & Receptive skills & $\begin{array}{c}2,3,5,6,7,8,9, \\
10,11,12,13,14 \\
15,16\end{array}$ & .90 & 111.94 & 58 & 1.93 & .90 & .80 & .09 \\
\hline 2 & Productive skills & $17-24$ & .88 & 15.83 & 13 & 1.21 & .96 & .90 & .04 \\
\hline 3 & ICT & $25-28$ & .79 & 7.54 & 2 & 3.77 & .96 & .90 & .10 \\
\hline 4 & $\begin{array}{l}\text { Grammar \& } \\
\text { vocabulary }\end{array}$ & $29,30,31,33,34$ & .80 & 1.60 & 3 & .53 & .99 & .97 & 0 \\
\hline 5 & Translation & $35-38$ & .80 & .75 & 1 & .75 & .99 & .96 & 0 \\
\hline 6 & $\begin{array}{l}\text { Feedback \& error } \\
\text { correction }\end{array}$ & $42-47$ & .95 & 12.97 & 6 & 2.16 & .96 & .90 & .10 \\
\hline 7 & $\begin{array}{l}\text { Assessment \& } \\
\text { evaluation }\end{array}$ & $48-51$ & .80 & 1.32 & 2 & .66 & .99 & .96 & 0 \\
\hline 8 & Classroom procedures & $39,40,41,52,53$ & .83 & .38 & 2 & .19 & .99 & .98 & 0 \\
\hline
\end{tabular}




\begin{tabular}{|c|l|c|c|c|c|c|c|c|c|}
\hline 9 & $\begin{array}{l}\text { ESAP syllabus \& } \\
\text { materials }\end{array}$ & $\begin{array}{c}55,57,59,60,61, \\
62,63,64\end{array}$ & .82 & 35.22 & 18 & 1.95 & .93 & .90 & .09 \\
\hline 10 & Students' needs & $65-72$ & .92 & 15.33 & 11 & 1.39 & .96 & .90 & .06 \\
\hline
\end{tabular}

Table 2. CFA results and reliability indices of ESAP teachers' teaching competence questionnaire (see Appendix A)

\begin{tabular}{|c|l|c|c|c|c|c|c|c|c|}
\hline No. & \multicolumn{1}{|c|}{ Factor } & Item numbers & Alpha & CMIN & DF & CMIN/DF & GFI & AGFI & RMSEA \\
\hline 1 & $\begin{array}{l}\text { Observation and } \\
\text { assistance from } \\
\text { other teachers }\end{array}$ & $1-5$ & .74 & .09 & 1 & .09 & 1 & .99 & 0 \\
\hline 2 & $\begin{array}{l}\text { Conference } \\
\text { participation and } \\
\text { research }\end{array}$ & $6-11$ & .94 & 2.75 & 2 & 1.37 & .99 & .91 & .06 \\
\hline 3 & $\begin{array}{l}\text { Personal } \\
\text { development }\end{array}$ & $\begin{array}{c}12,13,14,15, \\
16,18,19\end{array}$ & .75 & 12.55 & 10 & 1.25 & .97 & .90 & .05 \\
\hline
\end{tabular}

Table 3. CFA results and reliability indices of ESAP teachers' PD activities questionnaire (see Appendix B)

\begin{tabular}{|l|l|c|c|c|c|c|c|c|c|}
\hline No. & \multicolumn{1}{|c|}{ Factor } & Item numbers & Alpha & CMIN & DF & CMIN/DF & GFI & AGFI & RMSEA \\
\hline 1 & Receptive skills & $1-16$ & .91 & 168 & 22 & 3.00 & .95 & .90 & .06 \\
\hline 2 & ESAP materials & $17-19 \& 38$ & .71 & .58 & 2 & .29 & .99 & .99 & 0 \\
\hline 3 & Productive skills & $\begin{array}{c}20,21,22,23, \\
24,26,27\end{array}$ & .87 & 31.03 & 11 & 2.82 & .98 & .95 & .06 \\
\hline 4 & ICT & $28-31$ & .80 & 4.80 & 1 & 4.80 & .99 & .95 & .08 \\
\hline 5 & $\begin{array}{l}\text { Grammar \& } \\
\text { vocabulary }\end{array}$ & $32-37$ & .83 & 3.21 & 2 & 1.60 & .99 & .97 & .03 \\
\hline 6 & Translation & $39-42$ & .70 & 4.29 & 2 & 2.14 & .99 & .97 & .04 \\
\hline 7 & $\begin{array}{l}\text { Feedback \& error } \\
\text { correction }\end{array}$ & $46-51$ & .94 & 5.80 & 3 & 1.93 & .99 & .97 & .04 \\
\hline 8 & $\begin{array}{l}\text { Assessment \& } \\
\text { evaluation }\end{array}$ & $52-55$ & .71 & 1.66 & 1 & 1.66 & .99 & .98 & .03 \\
\hline 9 & $\begin{array}{l}\text { Classroom } \\
\text { procedures }\end{array}$ & $43-45 \& 56-58$ & .84 & 7.75 & 6 & 1.29 & .99 & .98 & .02 \\
\hline
\end{tabular}

Table 4. CFA results and reliability indices of ESAP teachers' classroom practices questionnaire (see Appendix C)

After removing a few items with factor loadings below 0.3 and making some model modifications, three separate questionnaires were obtained to explore ESAP 
teachers' teaching competence (Appendix A), ESAP teachers' PD activities (Appendix B), and students' perceptions of ESAP teachers' classroom practices (Appendix C) with acceptable model fitness indices and internal consistency coefficients. Tables 2, 3, and 4 show the CFA results as well as Cronbach's alpha coefficients of reliability for different sub-scales of the questionnaires.

\subsection{Procedure}

The data collection procedure was conducted in the 2018-2019 academic year. Out of 140 and 625 questionnaires distributed among the ESAP teachers and students, respectively, 105 and 502 were returned in person or via email, which resulted in response rates of $75 \%$ and $80 \%$, respectively. The participants were allowed sufficient time to complete the questionnaires in their native language, i.e. Persian. The anonymity and confidentiality of the collected data were guaranteed for the participants. Additionally, the teachers and students provided their informed consent and were informed that their participation was on a voluntary basis. The exclusion criteria were refusal to give informed consent, incomplete questionnaires, and unwillingness to continue the study.

\subsection{Design and data analysis}

The study involved the use of both descriptive and inferential statistics. The values of skewness and kurtosis did not exceed 2 and 7, respectively; thus, there was no departure from the normality assumption (West, Finch, \& Curran, 1995). Independent samples $t$ tests were performed to analyze the data. Moreover, Cronbach's alpha coefficients and CFA were used to examine the reliability and construct validity of the questionnaires, respectively.

\section{RESULTS}

To investigate the findings relating to RQ1, independent samples $t$ tests were run to explore any possible statistical differences between ESAP teachers (content and EL) regarding their beliefs about their ESAP teaching competence (Table 5). 


\begin{tabular}{|c|c|c|c|c|c|c|c|c|c|}
\hline \multirow[b]{2}{*}{ No. } & \multirow[b]{2}{*}{ Component } & \multirow[b]{2}{*}{ Items } & \multicolumn{2}{|c|}{$\begin{array}{l}\text { Levene's test for } \\
\text { equality of variances }\end{array}$} & \multirow[b]{2}{*}{$\begin{array}{c}\text { EL } \\
\text { teachers }\end{array}$} & \multirow[b]{2}{*}{$\begin{array}{l}\text { Content } \\
\text { teachers }\end{array}$} & \multicolumn{3}{|c|}{$\begin{array}{l}t \text { test for equality of } \\
\text { means }\end{array}$} \\
\hline & & & $\mathrm{F}$ & Sig. & & & $t$ & df & $\begin{array}{l}\text { Sig. } \\
(2- \\
\text { tailed })\end{array}$ \\
\hline 1 & Receptive skills & $\begin{array}{c}2,3,5,6,7,8,9 \\
10,11,12,13,14 \\
15,16\end{array}$ & .00 & .95 & 34.15 & 26.92 & 6.71 & 103 & .00 \\
\hline 2 & Productive skills & $17-24$ & 14.54 & .00 & 19.31 & 16.55 & 2.87 & 92.49 & .00 \\
\hline 3 & ICT & $25-28$ & .90 & .34 & 9.49 & 9.65 & -.38 & 103 & .70 \\
\hline 4 & $\begin{array}{l}\text { Grammar \& } \\
\text { vocabulary }\end{array}$ & $29,30,31,33,34$ & 9.13 & .00 & 13.47 & 10.28 & 7.57 & 85.88 & .00 \\
\hline 5 & Translation & $35-38$ & 11.06 & .00 & 9.18 & 9.48 & .64 & 94.89 & .52 \\
\hline 6 & $\begin{array}{l}\text { Feedback \& error } \\
\text { correction }\end{array}$ & $42-47$ & 9.97 & .22 & 14.88 & 10.30 & 6.44 & 91.28 & .00 \\
\hline 7 & $\begin{array}{l}\text { Assessment \& } \\
\text { evaluation }\end{array}$ & $48-51$ & 3.00 & .08 & 9.98 & 9.32 & 1.48 & 103 & .14 \\
\hline 8 & $\begin{array}{l}\text { Classroom } \\
\text { procedures }\end{array}$ & $39,40,41,52,53$ & 2.66 & .10 & 12.54 & 9.57 & 5.31 & 103 & .00 \\
\hline 9 & $\begin{array}{l}\text { ESAP syllabus \& } \\
\text { materials }\end{array}$ & $\begin{array}{c}55,57,59,60,61 \\
62,63,64\end{array}$ & .33 & .56 & 18.60 & 18.23 & .47 & 103 & .63 \\
\hline 10 & Students' needs & $65-72$ & .64 & .42 & 19.39 & 14.78 & 5.60 & 103 & .00 \\
\hline
\end{tabular}

Table 5. Results of descriptive statistics, Levene's test, and $t$ tests for ESAP teachers' teaching competence (see Appendix A)

As Table 5 shows, EL teachers have statistically significant higher means in different categories such as receptive skills $(t(103)=6.71, p=.00)$, productive skills $(t(92.49)=2.87, p=.00)$, grammar and vocabulary $(t(85.88)=7.57, p=.00)$, feedback and error correction $(t(91.28)=6.44, p=.00)$, classroom procedures $(t(103)=5.31, p=.00)$, and students' needs $(t(103)=5.60, p=.00)$. However, there were no statistically significant differences between the two groups in terms of ICT $(t(103)=-.38, p=.70)$, translation $(t(94.89)=.64, p=.52)$, assessment and evaluation $(t(103)=1.48, p=.14)$, and ESAP syllabus and materials $(t(103)=.47, p$ $=.63)$. It is noteworthy that EL teachers had slightly higher means in assessment and evaluation and ESAP syllabus and materials but slightly lower means in ICT and translation.

Similarly, independent samples $t$ tests were run to explore statistical differences between ESAP teachers (content and EL) in terms of their PD activities (Table 6). 


\begin{tabular}{|c|c|c|c|c|c|c|c|c|c|}
\hline \multirow{2}{*}{ No. } & \multirow{2}{*}{ Component } & \multirow{2}{*}{ Items } & \multicolumn{2}{|c|}{$\begin{array}{l}\text { Levene's test for } \\
\text { equality of } \\
\text { variances }\end{array}$} & \multirow{2}{*}{$\begin{array}{c}\text { EL } \\
\text { teachers }\end{array}$} & \multirow{2}{*}{$\begin{array}{l}\text { Content } \\
\text { teachers }\end{array}$} & \multicolumn{3}{|c|}{$\begin{array}{l}\text { t-test for equality of } \\
\text { means }\end{array}$} \\
\hline & & & $\mathrm{F}$ & Sig. & & & $\mathrm{t}$ & $\mathrm{df}$ & $\begin{array}{l}\text { Sig. (2- } \\
\text { tailed) }\end{array}$ \\
\hline 1 & $\begin{array}{l}\text { Observation \& } \\
\text { assistance from other } \\
\text { teachers }\end{array}$ & $\begin{array}{c}1,2,3,4, \& \\
5\end{array}$ & .15 & .69 & 9.49 & 8.17 & 3.43 & 103 & .00 \\
\hline 2 & $\begin{array}{l}\text { Conference } \\
\text { participation \& } \\
\text { research }\end{array}$ & $\begin{array}{c}6,7,8,9,10 \\
\& 11\end{array}$ & 22.21 & .00 & 13.00 & 7.67 & 8.42 & 86.28 & .00 \\
\hline 3 & Personal development & $\begin{array}{l}12,13,14 \\
15,16,18 \\
\quad \& 19\end{array}$ & .33 & .56 & 17.39 & 14.30 & 5.67 & 103 & .00 \\
\hline
\end{tabular}

Table 6. Results of descriptive statistics, Levene's test, and $t$ tests for ESAP teachers' PD activities (see Appendix B)

Table 6 indicates that EL teachers have statistically significant higher means in all three categories of PD activities, namely, observation and assistance from other teachers $(t(103)=3.43, p=.00)$, conference participation and research $(t(86.28)=8.42, p=.00)$, and personal development $(t(103)=5.67, p=.00)$.

For RQ3, independent samples $t$ tests were also run to explore any possible statistical differences between ESAP teachers' (content and EL) classroom practices as reported by their students (Table 7).

\begin{tabular}{|c|c|c|c|c|c|c|c|c|c|}
\hline \multirow[b]{2}{*}{ No. } & \multirow[b]{2}{*}{ Component } & \multirow[b]{2}{*}{ Items } & \multicolumn{2}{|c|}{$\begin{array}{c}\text { Levene's test for } \\
\text { equality of variances }\end{array}$} & \multirow[b]{2}{*}{$\begin{array}{c}\text { EL } \\
\text { teachers }\end{array}$} & \multirow[b]{2}{*}{$\begin{array}{l}\text { Content } \\
\text { teachers }\end{array}$} & \multicolumn{3}{|c|}{$t$ test for equality of means } \\
\hline & & & $\mathrm{F}$ & Sig. & & & $\mathrm{t}$ & df & $\begin{array}{c}\text { Sig. } \\
(2- \\
\text { tailed) }\end{array}$ \\
\hline 1 & Receptive skills & $1-16$ & .09 & .75 & 51.65 & 43.17 & 7.68 & 500 & .00 \\
\hline 2 & ESAP materials & $17-19 \& 38$ & .46 & .49 & 11.03 & 9.75 & 4.01 & 500 & .00 \\
\hline 3 & Productive skills & $\begin{array}{c}20,21,22 \\
23,24,26 \\
27\end{array}$ & .63 & .42 & 20.68 & 14.16 & 11.46 & 500 & .00 \\
\hline 4 & ICT & $28-31$ & .55 & .45 & 10.82 & 9.18 & 4.40 & 500 & .00 \\
\hline 5 & $\begin{array}{l}\text { Grammar \& } \\
\text { vocabulary }\end{array}$ & $32-37$ & 11.02 & .00 & 23.00 & 18.75 & 9.34 & 465.39 & .00 \\
\hline 6 & Translation & $39-42$ & 18.90 & .00 & 11.85 & 12.35 & -1.55 & 484.72 & .12 \\
\hline 7 & $\begin{array}{l}\text { Feedback \& error } \\
\text { correction }\end{array}$ & $46-51$ & .16 & .68 & 21.53 & 12.23 & 17.50 & 500 & .00 \\
\hline 8 & $\begin{array}{l}\text { Assessment \& } \\
\text { evaluation }\end{array}$ & $52-55$ & 19.87 & .00 & 14.70 & 10.47 & 14.34 & 438.32 & .00 \\
\hline
\end{tabular}

Table 7. Results of descriptive statistics, Levene's test, and $t$ tests for ESAP teachers' classroom practices (see Appendix C) 
Based on Table 7, EL teachers have statistically significant higher means in different categories, namely, receptive skills $(t(500)=7.68, p=.00)$, ESAP materials $(t(500)=4.01, p=.00)$, productive skills $(t(500)=11.46, p=.00), \operatorname{ICT}(t(500)=$ $4.40, p=.00)$, grammar and vocabulary $(t(465.39)=9.34, p=.00)$, feedback and error correction $(t(500)=17.50, p=.00)$, and assessment and evaluation $(t(438.32)$ $=14.34, p=.00)$. In addition, although content teachers' mean in translation ( $\mathrm{M}=$ $12.35)$ is higher than EL teachers $(M=11.85)$, this difference is not statistically significant $(t(484.72)=-1.55, p=.12)$.

\section{DISCUSSION}

The main objective of this study was to address and provide further empirical evidence for a recognized structural issue in the Iranian ESAP practitioner community, specifically divergences between the two ESAP teacher groups of English language and subject content teachers. This goal was achieved by developing overall profiles of the two groups in terms of their teaching competences, participation in PD activities, and classroom practices. In what follows, a comprehensive discussion of the findings is presented. The findings are then used to support the case for further EAP teacher development in a number of areas, which are outlined in the conclusion section.

\subsection{ESAP teachers' teaching competences}

In relation to the teaching competences of ESAP teachers (RQ1), the questionnaire results showed EL teachers' higher and statistically significant means in receptive skills, productive skills, grammar and vocabulary, feedback and error correction, classroom procedures, and students' needs as well as higher but not statistically significant means in assessment and evaluation and ESAP syllabus and materials. These findings are in line with Hejazi's (2013) observations and confirm the assertion that content teachers have "insufficient knowledge about English language methodology as well as low levels of competence in the areas of EAP instruction, course design, and needs analysis" (Rajabi et al., 2012: 280). EL teachers' greater competences could possibly be attributed to their higher general English proficiency (GEP) level, familiarity with different language teaching areas, and English language teaching experience (Hejazi, 2021).

\subsection{ESAP teachers' PD activities}

As to the findings relating to the PD activities of ESAP teachers (RQ2), the questionnaire results revealed that EL teachers had statistically higher means in 
observation and assistance from other teachers, conference participation and research, and personal development. This finding seems to indicate that EL teachers place more importance on, and are more actively involved in PD activities, which could have possibly led to their outperformance in this study, as elsewhere (e.g. Rajabi et al., 2012).

In fact, while PD in the field of ELT is fully fledged around the world (Borg, 2011), there is still limited research on EAP teachers' PD (Basturkmen, 2019; BlajWard, 2014) and a limited number of development opportunities in only few countries, e.g. the UK, for EAP teachers. However, as Bocanegra-Valle and Basturkmen (2019) emphasize, it is important for EAP teachers to undertake ongoing professional development. Similarly, Tao and Gao (2018) highlight the importance of creating increased PD activities and opportunities for EL teachers entering the EAP teaching field. As part of this, Blaj-Ward (2015) emphasizes the need for EAP teachers to enhance their 'research literacy' by engaging with theoretical and empirical research on EAP (Bahrami, Hosseini, \& Atai, 2019; Davis, 2019) and by conducting small- or large-scale studies on different practical aspects of EAP (Hamp-Lyons, 2018; Harwood, 2017).

\subsection{ESAP teachers' classroom practices}

When considering ESAP teachers' classroom practices (RQ3), the statistically significant higher means of EL teachers in the areas of receptive skills, ESAP materials, productive skills, ICT, grammar and vocabulary, feedback and error correction, and assessment and evaluation could indicate their higher potential and readiness to teach ESAP courses in the Iranian context. However, it is the case that most ESAP courses are taught by content teachers in Iranian universities, which has been the object of criticism of previous studies (e.g. Tavakoli \& Tavakol, 2018). The results of the present study are in line with past research indicating the higher performance of EL teachers in several areas, such as the implementation of the objectives of EAP instruction, EAP teaching methodology, course design, needs analysis, classroom management, and assessment (e.g. Atai \& Fatahi-Majd, 2014; Atai \& Taherkhani, 2018; Davoudi-Mobarakeh, Eslami-Rasekh, \& Barati, 2014; Rajabi et al., 2012). These differential findings between the instructional practices of EL and content teachers could be attributed to their contrasting cognitions on key EAP issues such as EAP goals, differences between EAP and English for General Purposes (EGP), and EAP teachers' qualifications and roles (Atai, Babaii, \& Lotfi Gaskaree, 2017).

Given the nature of EAP as highly focused on teaching (Anthony, 2018; Hyland \& Wong, 2019), the significance of teaching methodology in EAP (Hafner \& Miller, 2019; Hyland, 2006; Northcott, 2013), and the absence of EAP teacher education programs in Iran (Iranmehr et al., 2018), it seems that EL teachers could 
be considered better candidates to teach EAP courses thanks to their generic ELT qualifications and previous language teaching experience.

The statistically non-significant difference between the two ESAP teacher groups in translation might be justified in view of the fact that translation constitutes an essential part of EAP classes in Iran to the extent that not only content teachers but also EL teachers implement such activities in their classes, which has received intense criticism in past research (Tavakoli \& Tavakol, 2018).

\section{CONCLUSIONS}

The present study addressed the gap identified as the "little commentary literature concerning ESP [and EAP] teaching methodologies and teaching/learning activities" (Basturkmen, 2020: 6) by developing an overview of Iranian ESAP teachers' teaching competences, classroom practices, and PD activities. The findings suggest that EL teachers may be better positioned to teach ESAP courses than content teachers. Specific issues that emerged relating to the content teachers of ESAP were: low levels of GEP, insufficient familiarity with ESAP teaching skills, and excessive focus on translation in ESAP classes, as reported elsewhere (e.g. Rajabi et al., 2012).

However, despite the results of the present study and previous research indicating EL teachers' greater competence levels and readiness to teach ESAP courses in Iran, the reality is that most ESAP courses are offered by content departments that select who should teach them, i.e. a content or EL teacher, a situation that has consequently led to the preference for content teachers to teach the mandatory ESAP course(s) relating to their subject area. The situation is similar to Japan and some other Asian countries (Fukui, Noguchi, \& Watanabe, 2009), where content teachers are generally preferred since content knowledge "take[s] precedence over knowledge about language learning and teaching" (Anthony, 2011: 2).

This situation suggests that the EAP profession in Iran can be considered a 'peripheral support system' (Ding \& Bruce, 2017), a perception that negatively affects the position and identity of EAP teachers and EAP departments. Supporting this view of the marginal position of EAP in the Iranian higher education system is the study by Iranmehr et al. (2018), which suggests that content departments lack criteria for the selection, training, and evaluation of EAP teachers. Alongside this, the numbers of EAP departments are insufficient and, where they do exist, they have a perceived lower status. Generally, a lack of accountability and efficiency in the delivery of EAP are two inevitable outcomes, which can lead to marginalization of EAP in general and EAP teachers in particular in the Iranian context.

The present study used a cross-sectional survey design and self-reported questionnaires to provide an overview of the current EAP teacher situation in Iran. However, to build upon this study, future research could employ a longitudinal 
design and gather data through triangulation of other data collection techniques (e.g. focus-group interview, observation, life history narrative, and ethnography) and draw upon a wider range of sources (e.g. heads of EAP departments, policy makers, and vice deans of educational affairs in universities). It should also be noted that the study was conducted in the context of tertiary education in Iran, an expanding-circle country with its own unique cultural, educational, and social characteristics; thus, care should be taken in generalizing the findings to other contexts.

\section{IMPLICATIONS}

Implications of the findings of this study, along with those of previous research, suggest the need to invest in EL teachers via pre-service and in-service EAP teacher training programs/workshops, which is in line with BALEAP's (2008: 2) assumption for employing teachers with "post-experience training in the teaching of English and experience of studying at postgraduate level". For example, similar to the Turkish context (Kırkgöz, 2019), pre-service EAP teacher education programs could be designed and implemented for ESAP teachers in Iran. As a first step, it is suggested that more EAP/ESP modules be included in TESOL programs in Iran to address the real demands and needs of EAP teachers in universities. Such modules could refresh EL teachers' knowledge about practical aspects of language teaching, learning, and testing with a special focus on EAP. Additionally, some elective content modules on different subject-matter domains, such as medicine or engineering, could be presented to cater for teachers' need for disciplinary content knowledge and address the particular teaching and learning methodologies in different subjectmatter domains, e.g. problem solving in English for medical purposes (Basturkmen, 2010). This type of development could be a first step to establishing MA programs for EAP similar to those in the University of Leeds (https://www.leeds.ac.uk) and the University of Nottingham (https://www.nottingham.ac.uk) in the UK.

To underpin the implementation of these types of improvements, it is recommended that the Iranian Ministry of Science, Research, and Technology invest more in EAP research that supports and informs teacher development. Given the fact that the training needs of non-native EAP teachers, who constitute a large number of the global EAP teachers' community, are different from those in countries where English is the L1 (Hamp-Lyons, 2011), further research should be undertaken to design a local competency framework for PD and training of Iranian EAP teachers, similar to those developed in other contexts (Khamis, 2019; Pham \& Ta, 2016), or localize the CFTEAP (BALEAP, 2008, 2014). These developments could significantly contribute to establishing objective criteria for the recruitment and development of EAP teachers in the Iranian context. Additionally, considering the importance of close cooperation and collaboration among different stakeholders as a 'social need' (Basturkmen, 2019) for the successful 
implementation of EAP programs (Belcher, 2009; Hall, 2013; Hyland, 2019), further research is needed to investigate potential institutional and cultural barriers to the advancement of the EAP field and propose practical solutions to the current issues facing the field, some of which have been raised here.

Given EAP teachers' "plurality of interrelated necessities, concerns, expectations, lacks, and wants" (Bocanegra-Valle \& Basturkmen, 2019: 144), future studies could also explore the possible effect of teaching experience, qualifications, and PD on EL teachers' multi-faceted professional identity struggles while entering the EAP field. Considering the marginalization of EAP teachers in Iran and many other contexts like Canada (MacDonald, 2016), further research should systematically examine the Iranian ELT national curriculum as well as the actual practices and policies of higher education institutes to discover the major underlying reasons for this phenomenon and offer practical solutions to improve this situation.

EAP associations have considerable potential "for development of the knowledge base of the field, for practitioner formation, and for developing a collective voice for articulating and raising awareness of current issues, innovations, and concerns within a community, and EAP more widely" (Bruce, 2021: 33). Therefore, as one way of improving the status of EAP in the current Iranian higher education system, more national attention should be devoted to EAP as an important branch of English language teaching by organizing associations (similar to The Norwegian Forum for EAP and The China EAP Association) as well as EAP-specific events (similar to conferences held by BALEAP and the European Association of Languages for Specific Purposes). Finally, it is suggested that the Iranian Journal of English for Academic Purposes (IJEAP) take significant measures to draw and direct EAP researchers' attention to different under-researched EAP areas such as teacher development by running special issues and announcing call for papers similar to those published as 'Researching EAP Practices' in the Journal of English for Academic Purposes (JEAP).

[Paper submitted 16 Nov 2020]

[Revised version received 15 Apr 2021]

[Revised version accepted for publication 16 May 2021]

\section{Acknowledgments}

The authors would like to express their sincere appreciation to the Iranian EAP teachers as well as undergraduate students who actively participated in this study.

\section{References}

Alexander, O. (2012). Exploring teacher beliefs in teaching EAP at low proficiency levels. Journal of Englishfor Academic Purposes, 11(2), 99-111. https://doi.org/10.1016/j.jeap.2011.12.001 
Anthony, L. (2011). Products, processes and practitioners: A critical look at the importance of specificity in ESP. Taiwan International ESP Journal, 3(2), 19-50.

Anthony, L. (2018). Introducing English for specific purposes. Routledge.

Atai, M. R., \& Fatahi-Majd, M. (2014). Exploring the practices and cognitions of Iranian ELT instructors and subject teachers in teaching EAP reading comprehension. English for Specific Purposes, 33(1), 27-38. https://doi.org/10.1016/j.esp.2013.07.007

Atai, M. R., \& Hejazi, S. Y. (2019). Assessment of academic English language needs of Iranian post-graduate students of psychology. Ibérica, 38(2), 275-301.

Atai, M. R., \& Nazari, O. (2011). Exploring reading comprehension needs of Iranian EAP students of health information management (HIM): A triangulated perspective. System, 39(1), 30-43. https://doi.org/10.1016/j.system.2011.01.015

Atai, M. R., \& Nejadghanbar, H. (2017). Exploring Iranian ESP teachers' subject-related critical incidents.Journal of English for Academic Purposes, 29, 43-54. https://doi.org/10.1016/j.jeap.2017.08.001

Atai, M. R., \& Shoja, L. (2011). A triangulated study of academic language needs of Iranian students of computer engineering: Are the courses on track? RELC Journal, 42(3), 305-323. https://doi.org/10.1177/0033688211419392

Atai, M. R., \& Taherkhani, R. (2018). Exploring the cognitions and practices of Iranian EAP teachers in teaching the four language skills. Journal of English for Academic Purposes, 36, 108-118. https://doi.org/10.1016/j.jeap.2018.09.007

Atai, M. R., Babaii, E., \& Lotfi Gaskaree, B. (2017). EAP teacher cognition: A qualitative study of Iranian in-service EAP teachers' cognitions. Language Horizons, 1(2), 31-56. https://doi.org/10.22051/LGHOR.2018.15173.1055

Bahrami, V., Hosseini, M., \& Atai, M. R. (2019). Exploring research-informed practice in English for academic purposes: A narrative study. English for Specific Purposes, 54, 152-165. https://doi.org/10.1016/j.esp.2019.02.003

BALEAP. (2008). Competency framework for teachers of English for academic purposes. Retrieved from https://www.baleap.org/wp-content/uploads/2016/04/teapcompetency-framework.pdf

BALEAP. (2014). TEAP scheme handbook. Retrieved from https://www.baleap.org/wpcontent/uploads/2016/04/TEAP-Scheme-Handbook-2014.pdf

Basturkmen, H. (2010). Developing courses in English for specific purposes. Palgrave Macmillan.

Basturkmen, H. (2014). LSP teacher education: Review of literature and suggestions for the research agenda. Ibérica, 28, 17-34.

Basturkmen, H. (2019). ESP teacher education needs. Language Teaching, 52(3), 318-330. https://doi.org/10.1017/S0261444817000398

Basturkmen, H. (2020). Is ESP a materials and teaching-led movement? Language Teaching, 2020, 1-11. https://doi.org/10.1017/S0261444820000300

Basturkmen, H., \& Bocanegra-Valle, A. (2018). Materials design processes, beliefs and practices of experienced ESP teachers in university settings in Spain. In Y. Kırkgöz, \& K. Dikilitaş (Eds.), Key issues in English for specific purposes in higher education (pp. 13-27). Springer.

Belcher, D. (2009). What ESP is and can be: An introduction. In D. Belcher (Ed.), English for specific purposes in theory and practice (pp. 1-20). University of Michigan Press. 
Belcher, D. (2013). The future of ESP research: Resources and access and choice. In B. Paltridge, \& S. Starfield (Eds.), Handbook of English for specific purposes (pp. 535552). Blackwell.

Blaj-Ward, L. (2014). Researching contexts, practices and pedagogies in English for academic purposes. Palgrave Macmillan.

Blaj-Ward, L. (2015). Building research capacity through an AcLits-inspired pedagogical framework. In T. Lillis, K. Harrington, M. Lea, \& S. Mitchell (Eds.), Working with academic literacies: Research, theory, design (pp. 365-374). The WAC Clearinghouse/Parlor Press.

Bocanegra-Valle, A. (2016). Needs analysis for curriculum design. In P. Shaw, \& K. Hyland (Eds.), The Routledge handbook of English for academic purposes (pp. 584-600). Routledge.

Bocanegra-Valle, A., \& Basturkmen, H. (2019). Investigating the teacher education needs of experienced ESP teachers in Spanish universities. Ibérica, 38(2), 127-150.

Borg, S. (2011). Language teacher education. In J. Simpson (Ed.), The Routledge handbook of applied linguistics (pp. 215-228). Routledge.

Brown, J. D. (2016). Introducing needs analysis and English for specific purposes. Routledge.

Bruce, I. (2021). Towards an EAP without borders: Developing knowledge, practitioners, and communities. International Journal of English for Academic Purposes: Research and practice, 2021(Spring), 23-36. https://doi.org/10.3828/ijeap.2021.3

Campion, G. C. (2016). 'The learning never ends': Exploring teachers' views on the transition from general English to EAP. Journal of English for Academic Purposes, 23, 59-70. https://doi.org/10.1016/j.jeap.2016.06.003

Chang, K. C. C. (2017). From EAP to ESP: A teacher's identity development. Taiwan Journal of TESOL, 14(2), 71-100. https://doi.org/10.30397/TJTESOL.201710_14(2).0004

Charles, M., \& Pecorari, D. (2016). Introducing English for academic purposes. Routledge.

Chostelidou, D., Griva, E., \& Tsakiridou, E. (2009). A record of the training needs of ESP practitioners in vocational education. Selected Papers on Theoretical and Applied Linguistics, 18, 131-143. https://doi.org/10.26262/istal.v18i0.5432

Cohen, L., Manion, L., \& Morrison, K. (2011). Planning educational research: Research methods in education. Routledge.

Davis, M. (2019). Publishing research as an EAP practitioner: Opportunities and threats. Journal of English for Academic Purposes, 39, 72-86. https://doi.org/10.1016/j.jeap.2019.04.001

Davoudi-Mobarakeh, S., Eslami-Rasekh, A., \& Barati, H. (2014). Observation and feedback of content specialists versus general English teachers: Suggestions to make optimal English for specific purposes courses. Journal of English Language Teaching and Learning, 6(13), 15-41.

Ding, A. (2019). EAP practitioner identity. In K. Hyland, \& L. L. C. Wong (Eds.), Specialised English: New directions in ESP and EAP research and practice (pp. 63-75). Routledge.

Ding, A., \& Bruce, I. (2017). The English for academic purposes practitioner. Palgrave Macmillan.

Ding, A., \& Campion, G. (2016). EAP teacher development. In P. Shaw, \& K. Hyland (Eds.), The Routledge handbook of English for academic purposes (pp. 547-559). Routledge.

Dörnyei, Z. (2010). Questionnaires in second language research: Construction, administration, and processing. Routledge.

Dudley-Evans, T., \& St. John, M.-J. (1998). Developments in English for specific purposes: A multidisciplinary approach. Cambridge University Press. 
Fukui, K., Noguchi, J., \& Watanabe, N. (Eds.) (2009). Towards ESP bilingualism [in Japanese]. Osaka University Press.

Hafner, C. A., \& Miller, L. (2019). English in the disciplines: A multidimensional model for ESP course design. Routledge.

Hair, J. F., Anderson, R. E., Babin, B. J., \& Black, W. C. (2010). Multivariate data analysis: A global perspective. Pearson Education.

Hall, D. R. (2013). Teacher education for language for specific purposes. In C. A. Chapelle (Ed.), The encyclopedia of applied linguistics (pp. 5537-5542). Wiley-Blackwell. https://doi.org/10.1002/9781405198431.wbeal1144

Hamp-Lyons, L. (2011). What is EAP. In E. Hinkel (Ed.), Handbook of research in second language teaching and learning (pp. 89-105). Routledge.

Hamp-Lyons, L. (2018). Why researching EAP practice? Journal of English for Academic Purposes, 31, A3-A4. https://doi.org/10.1016/j.jeap.2017.12.010

Harwood, N. (2017). The EAP practitioner as researcher and disseminator of knowledge: Teaching EAP. Retrieved from https://teachingeap.files.wordpress.com/2017/01/restes-talknigel-harwood.pdf

Hejazi, S. Y. (2013). Assessment of academic English needs of Iranian post-graduate psychology students (Unpublished MA thesis). Kharazmi University, Tehran, Iran.

Hejazi, S. Y. (2021). Iranian English for specific purposes (ESP) teachers' practices and professional development needs (Unpublished doctoral dissertation). University of Tehran, Tehran, Iran.

Hutchinson, T., \& Waters, A. (1987). English for specific purposes. Cambridge University Press.

Hyland, K. (2006). English for academic purposes: An advanced resource book. Routledge.

Hyland, K. (2019). English for specific purposes: Some influences and impacts. In X. Gao (Ed.), Second handbook of English language teaching (pp. 337-353). Springer.

Hyland, K., \& Jiang, F. K. (2021). A bibliometric study of EAP research: Who is doing what, where and when? Journal of English for Academic Purposes, 49, Article 100929. https://doi.org/10.1016/j.jeap.2020.100929

Hyland, K., \& Wong, L. L. C. (2019). Introduction. In K. Hyland, \& L. L. C. Wong (Eds.), Specialised English: New directions in ESP and EAP research and practice (pp. 1-5). Routledge.

Iranmehr, A., Atai, M. R., \& Babaii, E. (2018). Evaluation of EAP programs in Iran: Document analysis and expert perspectives. Applied Research on English Language, 7(2), 171-194. https://doi.org/10.22108/ARE.2018.104481.1123

Jing, L. (2010). An explorative study of Chinese college English teachers' professional development. Journal of Asia TEFL, 7(4), 1-28.

Kaivanpanah, S., Alavi, S. M., Bruce, I., \& Hejazi, S. Y. (2021). EAP in the expanding circle: Exploring the knowledge base, practices, and challenges of Iranian EAP practitioners. Journal of English for Academic Purposes, 50, Article 100971. https://doi.org/10.1016/j.jeap.2021.100971

Khamis, N. Y. (2019). A new competency-based framework for English for specific engineering purposes (ESEP) practitioners. The Asian EFL Journal, 23(6.3), 46-65.

Kırkgöz, Y. (2019). ESP in teacher education: A case study. In S. Papadima-Sophocleous, E. K. Constantinou, \& C. N. Giannikas (Eds.), ESP teaching and teacher education: Current theories and practices (pp. 13-26). Research-publishing.net. 
Li, Y., \& Ma, X. (2020). Chinese EAP teachers' graduate-level English academic writing instruction and their professional development. Ibérica, 39(1), 141-164.

Li, Y., \& Wang, L. (2018). An ethnography of Chinese college English teachers' transition from teaching English for general purposes to teaching English for academic purposes. ESP Today, 6(1), 107-124. https://doi.org/10.18485/esptoday.2018.6.1.6

Liu, Y., \& Hu, G. (2021). Mapping the field of English for specific purposes (1980-2018): A co-citation analysis. English for Specific Purposes, 61, 97-116. https://doi.org/10.1016/j.esp.2020.10.003

MacDonald, J. (2016). The margins as third space: EAP teacher professionalism in Canadian universities. TESL Canada Journal, 34(1), 106-116. https://doi.org/10.18806/tesl.v34i1.1258

Mazdayasna, G., \& Tahririan, M. H. (2008). Developing a profile of the ESP needs of Iranian students: The case of students of nursing and midwifery. Journal of English for Academic Purposes, 7(4), 277-289. https://doi.org/10.1016/j.jeap.2008.10.008

Nazari, M. (2020). Language for specific purposes teacher education: A scoping review. MexTesol, 44(4), 1-13.

Nguyen, B. H., Haworth, P., \& Hansen, S. (2019). Challenging ESP teacher beliefs about active learning in a Vietnamese university. Teacher Development, 23(3), 345-365. https://doi.org/10.1080/13664530.2019.1598481

Northcott, J. (2013). Methods for language for specific purposes. In C. A. Chapelle (Ed.), The encyclopedia of applied linguistics (pp. 3676-3682). Wiley-Blackwell. https://doi.org/10.1002/9781405198431.wbeal0764

Pérez-Llantada, C., \& Swales, M. J. (2017). English for academic purposes. In E. Hinkel (Ed.), Handbook of research in second language teaching and learning (pp. 42-55). Routledge.

Pham, H. A., \& Ta, B. T. (2016). Developing a theoretical framework for ESP teacher training in Vietnam. The Asian ESP Journal, 12(2), 66-84.

Rajabi, P., Kiany, G. R., \& Maftoon, P. (2012). ESP in-service teacher training programs: Do they change Iranian teachers' beliefs, classroom practices and students' achievements? Ibérica, 24(2), 261-282.

Riazi, A. M., Ghanbar, H., \& Fazel, I. (2020). The contexts, theoretical and methodological orientation of EAP research: Evidence from empirical articles published in the Journal of English for Academic Purposes. Journal of English for Academic Purposes, 48, Article 100925. https://doi.org/10.1016/j.jeap.2020.100925

Richards, J. C. (1998). Beyond training: Perspectives on language teacher education. Cambridge University Press.

Soodmand Afshar, H. S., \& Movassagh, H. (2016). EAP education in Iran: Where does the problem lie? Where are we heading? Journal of English for Academic Purposes, 22, 132-151. https://doi.org/10.1016/j.jeap.2016.04.002

Stoller, F. L. (2016). EAP materials and tasks. In P. Shaw, \& K. Hyland (Eds.), The Routledge handbook of English for academic purposes (pp. 577-591). Routledge.

Taherkhani, R. (2019). A nationwide study of Iranian language teachers' and content teachers' cognitions and practices of collaborative EAP teaching. Iranian Journal of Language Teaching Research, 7(2), 121-139. https://doi.org/10.30466/ijltr.2019.120701

Tao, J. T., \& Gao, X. A. (2018). Identity constructions of ESP teachers in a Chinese university. English for Specific Purposes, 49, 1-13. https://doi.org/10.1016/j.esp.2017.09.003 
Tavakoli, M., \& Tavakol, M. (2018). Problematizing EAP education in Iran: A critical ethnographic study of educational, political, and sociocultural roots. Journal of English for Academic Purposes, 31, 28-43. https://doi.org/10.1016/j.jeap.2017.12.007

West, S. G., Finch, J. F., \& Curran, P. J. (1995). Structural equation models with nonnormal variables: Problems and remedies. In R. H. Hoyle (Ed.), Structural equation modeling: Concepts, issues, and applications (pp. 56-75). Sage.

Wichadee, S. (2012). Factors related to professional development of English language university teachers in Thailand. Journal of Education for Teaching, 38(5), 615-627. https://doi.org/10.1080/02607476.2013.739795

Woodrow, L. (2018). Introducing course design in English for specific purposes. Routledge.

Worthington, R. L., \& Whittaker, T. A. (2006). Scale development research: A content analysis and recommendations for best practices. The Counseling Psychologist, 34(6), 806-838. https://doi.org/10.1177/0011000006288127

SHIVA KAIVANPANAH is an associate professor at the University of Tehran (Iran). She has published a number of papers in academic journals. Her current research interests include vocabulary studies, teacher education, and issues in teaching academic writing to English language learners.

SAYYED MOHAMMAD ALAVI is a professor of applied linguistics in the University of Tehran (Iran). He teaches language teaching methodology, language testing and assessment, and teacher education courses. He has published in prestigious international journals such as Language Assessment Quarterly, Language Testing Journal, RELC Journal, and The Language Learning Journal.

IAN BRUCE is a senior lecturer in applied linguistics at the University of Waikato (New Zealand). His research involves the analysis of academic, professional, and journalistic genres, and his publications are in the areas of genre studies and academic writing. His most recent book is Expressing critical thinking through disciplinary texts: Insights from five genre studies (Bloomsbury, 2020).

S. YAHYA HEJAZI is a PhD candidate in Teaching English as a Foreign Language (TEFL) in the University of Tehran (Iran). He has been a research scholar at the Victoria University of Wellington (NZ) and taught as a visiting lecturer at some Iranian universities. His current research interests include English for specific/academic purposes (ESP/EAP) and educational psychology. 


\section{Appendix $A$}

\section{ESAP Teachers' Teaching Competences}

Age: .... Gender: ...... Major: ............. University: ..........

ESAP teaching experience: ............. (years)

Background: TEFL subject-matter (If you are from a subject-matter background, please mention your major)

Dear ESAP teacher,

Please kindly indicate your present level of ability in the following areas. Thank you very much for your effective cooperation.

\begin{tabular}{|c|c|c|c|c|}
\hline No. & SKILL & $\begin{array}{l}\text { NEED IMPROVEMENT } \\
(\%)\end{array}$ & $\begin{array}{l}\text { Proficient } \\
(\%)\end{array}$ & $\begin{array}{l}\text { VERY PROFICIENT } \\
\text { (\%) }\end{array}$ \\
\hline 1. & $\begin{array}{l}\text { Activating students' subject-matter background } \\
\text { knowledge before reading the texts }\end{array}$ & & & \\
\hline 2. & Teaching how to preview a text & & & \\
\hline 3. & Teaching how to predict or guess the text meaning & & & \\
\hline 4. & $\begin{array}{l}\text { Teaching how to critically evaluate technical } \\
\text { information in written texts }\end{array}$ & & & \\
\hline 5. & $\begin{array}{l}\text { Teaching how to take notes while reading technical } \\
\text { texts }\end{array}$ & & & \\
\hline 6. & Teaching how to scan EAP texts & & & \\
\hline 7. & Teaching how to skim EAP texts & & & \\
\hline 8. & $\begin{array}{l}\text { Teaching how to guess the meaning of unknown words } \\
\text { from context while reading }\end{array}$ & & & \\
\hline 9. & Teaching how to get the text main idea & & & \\
\hline 10. & $\begin{array}{l}\text { Teaching how to draw conclusions and understand } \\
\text { implied meanings while reading }\end{array}$ & & & \\
\hline 11. & Teaching how to predict content while listening & & & \\
\hline 12. & Teaching how to listen for main ideas while listening & & & \\
\hline 13. & $\begin{array}{l}\text { Teaching how to pay attention to transitional signals } \\
\text { while listening }\end{array}$ & & & \\
\hline 14. & $\begin{array}{l}\text { Teaching how to infer the meaning of unknown words } \\
\text { while listening }\end{array}$ & & & \\
\hline 15. & $\begin{array}{l}\text { Teaching how to summarize information while } \\
\text { listening }\end{array}$ & & & \\
\hline 16. & $\begin{array}{l}\text { Teaching students how to pay attention to details in } \\
\text { listening }\end{array}$ & & & \\
\hline 17. & Familiarizing students with how to write abstracts & & & \\
\hline 18. & $\begin{array}{l}\text { Familiarizing students with how to write different } \\
\text { parts of a research paper }\end{array}$ & & & \\
\hline 19. & Teaching how to write short technical essays & & & \\
\hline 20. & $\begin{array}{l}\text { Teaching essential skills for correspondence with } \\
\text { subject-matter specialists, journal editors, etc. }\end{array}$ & & & \\
\hline 21. & Teaching how to write a professional CV in English & & & \\
\hline 22. & Teaching correct pronunciation & & & \\
\hline 23. & $\begin{array}{l}\text { Providing students with opportunities for delivering } \\
\text { lectures in English }\end{array}$ & & & \\
\hline 24. & $\begin{array}{l}\text { Providing opportunities for students to speak in } \\
\text { English in class }\end{array}$ & & & \\
\hline 25. & Using slides and video projector & & & \\
\hline 26. & $\begin{array}{l}\text { Teaching students how to use/search scientific } \\
\text { academic databases }\end{array}$ & & & \\
\hline 27. & Using ICT and multimedia in EAP classes & & & \\
\hline 28. & Using electronic sources (e.g. dictionaries) in class & & & \\
\hline
\end{tabular}




\begin{tabular}{|c|c|c|c|c|}
\hline 29. & $\begin{array}{l}\text { Teaching the required grammar for understanding } \\
\text { technical academic texts }\end{array}$ & & & \\
\hline 30. & Teaching collocations & & & \\
\hline 31. & Teaching general English vocabulary & & & \\
\hline 32. & Teaching subject-related vocabulary (technical terms) & & & \\
\hline 33. & $\begin{array}{l}\text { Focusing on the structure of technical terms (e.g. } \\
\text { prefixes, suffixes, etc.) to facilitate learning them }\end{array}$ & & & \\
\hline 34. & $\begin{array}{l}\text { Teaching how to guess the meaning of unknown } \\
\text { technical words }\end{array}$ & & & \\
\hline 35. & Providing students with comments on their translation & & & \\
\hline 36. & Assigning texts for translation & & & \\
\hline 37. & Translating texts into Persian & & & \\
\hline 38. & Translating texts into English & & & \\
\hline 39. & Explaining technical terms in English & & & \\
\hline 40. & $\begin{array}{l}\text { Using English as the main medium of instruction in } \\
\text { class }\end{array}$ & & & \\
\hline 41. & $\begin{array}{l}\text { Using English to give feedback to students' } \\
\text { performance in class }\end{array}$ & & & \\
\hline 42. & Providing feedback on students' speaking fluency & & & \\
\hline 43. & Providing feedback on students' speaking accuracy & & & \\
\hline 44. & Providing feedback on students' writing fluency & & & \\
\hline 45. & Providing feedback on students' writing accuracy & & & \\
\hline 46. & Providing feedback on students' writing organization & & & \\
\hline 47. & $\begin{array}{l}\text { Providing feedback on students' use of different } \\
\text { structures }\end{array}$ & & & \\
\hline 48. & Using different assessment and evaluation techniques & & & \\
\hline 49. & Giving mid-term examination & & & \\
\hline 50. & Giving Quizzes & & & \\
\hline 51. & $\begin{array}{l}\text { Asking questions orally in the beginning or during the } \\
\text { class period }\end{array}$ & & & \\
\hline 52. & $\begin{array}{l}\text { Choosing appropriate methods for teaching EAP like } \\
\text { pair/group work, role play, group discussion, etc. }\end{array}$ & & & \\
\hline 53. & Involving students in classroom activities & & & \\
\hline 54. & Assigning homework & & & \\
\hline 55. & Using content-related video/audio clips & & & \\
\hline 56. & $\begin{array}{l}\text { Using up-to-date textbooks (published in the past } 10 \\
\text { years) in teaching reading }\end{array}$ & & & \\
\hline 57. & $\begin{array}{l}\text { Using up-to-date research papers (published in the } \\
\text { past } 10 \text { years) in teaching reading }\end{array}$ & & & \\
\hline 58. & $\begin{array}{l}\text { Introducing technical dictionaries and teaching } \\
\text { students how to use them }\end{array}$ & & & \\
\hline 59. & Designing syllabus for EAP courses & & & \\
\hline 60. & Producing materials for teaching EAP & & & \\
\hline 61. & Adapting materials for teaching EAP & & & \\
\hline 62. & Choosing authentic materials for teaching EAP & & & \\
\hline 63. & Choosing relevant content for EAP teaching & & & \\
\hline 64. & $\begin{array}{l}\text { Developing appropriate activities/exercises for EAP } \\
\text { materials used in the class }\end{array}$ & & & \\
\hline 65. & Identifying students' target situation needs in reading & & & \\
\hline 66. & Identifying students' target situation needs in writing & & & \\
\hline 67. & Identifying students' target situation needs in listening & & & \\
\hline 68. & Identifying students' target situation needs in speaking & & & \\
\hline 69. & Addressing students' target situation needs in reading & & & \\
\hline 70. & Addressing students' target situation needs in writing & & & \\
\hline 71. & Addressing students' target situation needs in listening & & & \\
\hline 72. & Addressing students' target situation needs in speaking & & & \\
\hline
\end{tabular}




\section{Appendix $B$}

\section{ESAP Teachers' Professional Development Activities}

Dear ESAP teacher,

Please indicate how often you have performed the following professional development activities in the last 12 months. Thank you for your kind attention.

\begin{tabular}{|c|c|c|c|c|}
\hline No. & Professional Development Activities & $\begin{array}{c}\text { Never } \\
(\%)\end{array}$ & $\begin{array}{c}\text { Sometimes } \\
(\%)\end{array}$ & $\begin{array}{l}\text { Always } \\
(\%)\end{array}$ \\
\hline 1. & Observing other EAP classes & & & \\
\hline 2. & Attending an EAP teaching demonstration of an expert & & & \\
\hline 3. & Asking colleagues to observe your teaching and offer feedback & & & \\
\hline 4. & $\begin{array}{l}\text { Discussing or sharing knowledge related to teaching ELT/EAP } \\
\text { with colleagues in informal dialogues }\end{array}$ & & & \\
\hline 5. & $\begin{array}{l}\text { Discussing or sharing knowledge related to EAP teachers' } \\
\text { professional development with colleagues }\end{array}$ & & & \\
\hline 6. & $\begin{array}{l}\text { Attending national/international conferences/seminars related } \\
\text { to EAP/ELT }\end{array}$ & & & \\
\hline 7. & Attending national/international workshops related to EAP/ELT & & & \\
\hline 8. & $\begin{array}{l}\text { Attending national/international short courses related to } \\
\text { EAP/ELT }\end{array}$ & & & \\
\hline 9. & Doing research concerning ELT/EAP & & & \\
\hline 10. & Publishing papers in academic journals related to EAP/ELT & & & \\
\hline 11. & $\begin{array}{l}\text { Presenting a paper in national/international conferences related } \\
\text { to language teaching or EAP }\end{array}$ & & & \\
\hline 12. & $\begin{array}{l}\text { Membership in national/international associations related to } \\
\text { ELT/EAP }\end{array}$ & & & \\
\hline 13. & $\begin{array}{l}\text { Reading professional textbooks, journals, or research papers } \\
\text { related to EAP/ELT }\end{array}$ & & & \\
\hline 14. & $\begin{array}{l}\text { Searching for knowledge related to teaching general or academic } \\
\text { English on the Internet/books }\end{array}$ & & & \\
\hline 15. & $\begin{array}{l}\text { Searching for knowledge related to assessing general or } \\
\text { academic English on the Internet/books }\end{array}$ & & & \\
\hline 16. & Regular review of one's own EAP teaching & & & \\
\hline 17. & Taking part in general English classes & & & \\
\hline 18. & Downloading subject-matter lectures from YouTube, etc. & & & \\
\hline 19. & Learning how to use new technologies in EAP classes & & & \\
\hline
\end{tabular}

\section{Appendix C}

\section{ESAP Teachers' Classroom Practices}

Age: ............ Major: ............. University: ............. Gender:

Does your teacher have a TEFL background? Yes $\quad \square \quad$ No

Dear student,

The present study aims to explore ESAP teachers' classroom practices. Please kindly indicate how frequently your ESAP teacher performs the following activities in your ESAP class. Your answers will be completely confidential. In case you are interested in the final results of this study, please provide us with your email address. Thank you very much for your effective cooperation. 


\begin{tabular}{|c|c|c|c|c|c|c|}
\hline No. & SKILL & $\begin{array}{l}\text { NEVER } \\
(\%)\end{array}$ & $\begin{array}{l}\text { SELDOM } \\
(\%)\end{array}$ & $\begin{array}{l}\text { SOMETIMES } \\
(\%)\end{array}$ & $\begin{array}{l}\text { OFTEN } \\
(\%)\end{array}$ & $\begin{array}{l}\text { AlWAYS } \\
(\%)\end{array}$ \\
\hline 1. & $\begin{array}{l}\text { Activating students' subject-matter } \\
\text { background knowledge before reading the } \\
\text { texts }\end{array}$ & & & & & \\
\hline 2. & Teaching how to preview a text & & & & & \\
\hline 3. & $\begin{array}{l}\text { Teaching how to predict or guess the text } \\
\text { meaning }\end{array}$ & & & & & \\
\hline 4. & $\begin{array}{l}\text { Teaching how to critically evaluate } \\
\text { technical information in written texts }\end{array}$ & & & & & \\
\hline 5. & $\begin{array}{l}\text { Teaching how to take notes while reading } \\
\text { technical texts }\end{array}$ & & & & & \\
\hline 6. & Teaching how to scan EAP texts & & & & & \\
\hline 7. & Teaching how to skim EAP texts & & & & & \\
\hline 8. & $\begin{array}{l}\text { Teaching how to guess the meaning of } \\
\text { unknown words from context while } \\
\text { reading }\end{array}$ & & & & & \\
\hline 9. & Teaching how to get the text main idea & & & & & \\
\hline 10. & $\begin{array}{l}\text { Teaching how to draw conclusions and } \\
\text { understand implied meanings while } \\
\text { reading }\end{array}$ & & & & & \\
\hline 11. & $\begin{array}{l}\text { Teaching how to predict content while } \\
\text { listening }\end{array}$ & & & & & \\
\hline 12. & $\begin{array}{l}\text { Teaching how to listen for main ideas } \\
\text { while listening }\end{array}$ & & & & & \\
\hline 13. & $\begin{array}{l}\text { Teaching how to pay attention to } \\
\text { transitional signals while listening }\end{array}$ & & & & & \\
\hline 14. & $\begin{array}{l}\text { Teaching how to infer the meaning of } \\
\text { unknown words while listening }\end{array}$ & & & & & \\
\hline 15. & $\begin{array}{l}\text { Teaching how to summarize information } \\
\text { while listening }\end{array}$ & & & & & \\
\hline 16. & $\begin{array}{l}\text { Teaching students how to pay attention to } \\
\text { details in listening }\end{array}$ & & & & & \\
\hline 17. & Using content-related video/audio clips & & & & & \\
\hline 18. & $\begin{array}{l}\text { Using up-to-date textbooks (published in } \\
\text { the past } 10 \text { years) in teaching reading }\end{array}$ & & & & & \\
\hline 19. & $\begin{array}{l}\text { Using up-to-date research papers } \\
\text { (published in the past } 10 \text { years) in } \\
\text { teaching reading }\end{array}$ & & & & & \\
\hline 20. & $\begin{array}{l}\text { Familiarizing students with how to write } \\
\text { abstracts }\end{array}$ & & & & & \\
\hline 21. & $\begin{array}{l}\text { Familiarizing students with how to write } \\
\text { different parts of a research paper }\end{array}$ & & & & & \\
\hline 22. & $\begin{array}{l}\text { Teaching how to write short technical } \\
\text { essays }\end{array}$ & & & & & \\
\hline 23. & $\begin{array}{l}\text { Teaching essential skills for } \\
\text { correspondence with subject-matter } \\
\text { specialists, journal editors, etc. }\end{array}$ & & & & & \\
\hline 24. & $\begin{array}{l}\text { Teaching how to write a professional CV in } \\
\text { English }\end{array}$ & & & & & \\
\hline 25. & Teaching correct pronunciation & & & & & \\
\hline 26. & $\begin{array}{l}\text { Providing students with opportunities for } \\
\text { delivering lectures in English }\end{array}$ & & & & & \\
\hline 27. & $\begin{array}{l}\text { Providing opportunities for students to } \\
\text { speak in English in class }\end{array}$ & & & & & \\
\hline 28. & Using slides \& video projector & & & & & \\
\hline
\end{tabular}




\begin{tabular}{|c|c|c|c|c|c|c|}
\hline 29. & $\begin{array}{l}\text { Teaching students how to use/search } \\
\text { scientific academic databases }\end{array}$ & & & & & \\
\hline 30. & Using ICT and multimedia in EAP classes & & & & & \\
\hline 31. & $\begin{array}{l}\text { Using electronic sources (e.g. dictionaries) } \\
\text { in class }\end{array}$ & & & & & \\
\hline 32. & $\begin{array}{l}\text { Teaching the required grammar for } \\
\text { understanding technical academic texts }\end{array}$ & & & & & \\
\hline 33. & Teaching collocations & & & & & \\
\hline 34. & Teaching general English vocabulary & & & & & \\
\hline 35. & $\begin{array}{l}\text { Teaching subject-related vocabulary } \\
\text { (technical terms) }\end{array}$ & & & & & \\
\hline 36. & $\begin{array}{l}\text { Focusing on the structure of technical } \\
\text { terms (e.g. prefixes, suffixes, etc.) to } \\
\text { facilitate learning them }\end{array}$ & & & & & \\
\hline 37. & $\begin{array}{l}\text { Teaching how to guess the meaning of } \\
\text { unknown technical words }\end{array}$ & & & & & \\
\hline 38. & $\begin{array}{l}\text { Introducing technical dictionaries and } \\
\text { teaching students how to use them }\end{array}$ & & & & & \\
\hline 39. & $\begin{array}{l}\text { Providing students with comments on } \\
\text { their translation }\end{array}$ & & & & & \\
\hline 40. & Assigning texts for translation & & & & & \\
\hline 41. & Translating texts into Persian & & & & & \\
\hline 42. & Translating texts into English & & & & & \\
\hline 43. & Explaining technical terms in English & & & & & \\
\hline 44. & $\begin{array}{l}\text { Using English as the main medium of } \\
\text { instruction in class }\end{array}$ & & & & & \\
\hline 45. & $\begin{array}{l}\text { Using English to give feedback to students' } \\
\text { performance in class }\end{array}$ & & & & & \\
\hline 46. & $\begin{array}{l}\text { Providing feedback on students' speaking } \\
\text { fluency }\end{array}$ & & & & & \\
\hline 47. & $\begin{array}{l}\text { Providing feedback on students' speaking } \\
\text { accuracy }\end{array}$ & & & & & \\
\hline 48. & $\begin{array}{l}\text { Providing feedback on students' writing } \\
\text { fluency }\end{array}$ & & & & & \\
\hline 49. & $\begin{array}{l}\text { Providing feedback on students' writing } \\
\text { accuracy }\end{array}$ & & & & & \\
\hline 50. & $\begin{array}{l}\text { Providing feedback on students' writing } \\
\text { organization }\end{array}$ & & & & & \\
\hline 51. & $\begin{array}{l}\text { Providing feedback on students' use of } \\
\text { different structures }\end{array}$ & & & & & \\
\hline 52. & $\begin{array}{l}\text { Using different assessment and evaluation } \\
\text { techniques }\end{array}$ & & & & & \\
\hline 53. & Giving mid-term examination & & & & & \\
\hline 54. & Giving quizzes & & & & & \\
\hline 55. & $\begin{array}{l}\text { Asking questions orally in the beginning or } \\
\text { during the class period }\end{array}$ & & & & & \\
\hline 56. & $\begin{array}{l}\text { Choosing appropriate methods for } \\
\text { teaching EAP like pair/group work, role } \\
\text { play, group discussion, etc. }\end{array}$ & & & & & \\
\hline 57. & Involving students in classroom activities & & & & & \\
\hline 58. & Assigning homework & & & & & \\
\hline
\end{tabular}

